\title{
Effect of Sources and Levels of Dietary Zinc on the Performance, Carcass Traits and Blood Parameters of Broilers
}

\section{-Author(s)}

\section{Zakaria $\mathrm{HA}$}

Jalal $\mathrm{M}^{\prime}$

AL-Titi HH

Souad $A^{\prime}$

Animal Production Department, Faculty of Agriculture, The University of Jordan, Amman-11942, Jordan.

\section{-Mail Address}

Corresponding author e-mail address Hana Abdul-Hadi Zakaria

Animal Production Department, Faculty of Agriculture, The University of Jordan,

Amman-11942, Jordan.

Tel: $\quad 00962798515389$

Email: zakariah@ju.edu.jo

\section{EKeywords}

Broilers, Performance, Carcass, Blood parameters, Zinc sources and levels.

\section{ABSTRACT}

A total of 400 one-day-old, straight-run, commercial (Ross 308) broiler chicks were used to evaluate the effects of two dietary levels of zinc (Zn) sources on broiler chick performance, carcass traits and blood parameters. Corn-soybean diets were formulated for three rearing phases (starter, grower and finisher). The two dietary treatments applied consisted of the addition per $\mathrm{kg}$ of diet of $80 \mathrm{mg}$ of inorganic $\mathrm{Zn}(\mathrm{ZnO})$ (T1), or $80 \mathrm{mg}$ of $\mathrm{ZnO}$ plus $42 \mathrm{mg}$ of an organic $\mathrm{Zn}$-amino acid complex (Availa-Zn120; Zinpro Corporation, Eden Prairie, MN, USA), totaling $122 \mathrm{mg}$ of the combined organic and inorganic Zn sources (T2). Birds were distributed according to a completely randomized design in the two treatments with eight replicates (pens) of 25 birds each. Feed and water were provided ad libitum. On day 42, blood samples were taken from four birds closest to the group average weight per replicate (32 per treatment) and then slaughtered for carcass evaluation. The results of this study did not find any significant effect of either of the evaluated Zn sources on broiler growth performance. Mortality rate was significantly lower $(p<0.05)$ by the higher $\mathrm{Zn}$ concentration and the $\mathrm{Zn}$ sources group (T2). Carcass yields were not significantly influenced by the treatments. Breast quality showed significant improvement $(p<0.05)$ in shear force (T2), indicating juicier meat. Higher concentrations $(p<0.05)$ of $\mathrm{Zn}$, Phosphorus (P), and total protein in blood were noted in (T2). Birds fed a mixture of organic and inorganic Zn source (T2) presented overall better results.

\section{INTRODUCTION}

Zinc $(Z n)$ is an essential trace element in all living systems - from bacteria, plants and animals to humans - and plays an important role in various biological activities in animals, especially in fast-growing poultry (Liu et al., 2011). Poultry diets are commonly supplemented with Zn since many feed ingredients are marginally deficient in this trace element (Bao et al., 2007). The variable content of $Z n$ in poultry feeds, particularly in the components of concentrate mixtures for poultry, and the fact that Zn binds with phytic acid inside the intestine to form complexes that make it unavailable for absorption, justifies the necessity to maintain a proper balance of this element in the feed mixture (Yan and Waldroup, 2006). $Z n$ is added to broiler diets in inorganic feed-grade forms, such as zinc sulfate $\left(\mathrm{ZnSO}_{4}\right.$ ) (Rossi et al., 2007) or zinc oxide (ZnO) (Wojciech et al., 2007, Jahanian et al., 2014). Organic Zn sources, such as Zn methionine ( $Z n-M e)$ and $Z n$ amino acid complex (ZnAA), have been used in the poultry feed industry owing to their potentially higher $\mathrm{Zn}$ bioavailability (Berger et al., 2006; Salim et al., 2010) when compared with the inorganic forms. Generally, it is accepted that bioavailability of trace mineral supplements from organic sources is higher than that of the inorganic sources owing to the ability of organic compounds, such as 
amino acids, to bind strongly to divalent minerals under physiological pH conditions (Cheng et al., 2005; Yan and Waldroup, 2006; Ao et al., 2009). Conflicting data have been reported regarding the relative efficacy of different organic compared with inorganic Zn sources in enhancing broiler performance (Hess et al., 2001; Swiatkiewicz et al., 2001). Zn requirements have been estimated to be $37 \mathrm{mg} / \mathrm{kg}$ from organic sources (Ao et al., 2007) and $84 \mathrm{mg} / \mathrm{kg}$ from inorganic sources (Huang et al., 2007). The National Research Council (NRC, 1994) states that $\mathrm{Zn}$ requirements of broilers are $40 \mathrm{mg} / \mathrm{kg}$ regardless of the source. However, poultry diets are often formulated to contain dietary Zn concentrations over $80 \mathrm{mg} / \mathrm{kg}$ to achieve maximum performance (Jahanian et al., 2014). Producers of Ross (308) chicks recommend $100 \mathrm{mg} / \mathrm{kg}$ for $\mathrm{Zn}$. Burrell et al. (2004) reported improved performance when broilers consumed diets formulated to contain $110 \mathrm{mg}$ $\mathrm{Zn} / \mathrm{kg}$. Excessive supplementation of inorganic $\mathrm{Zn}$ can cause environmental pollution resulting from the low utilization of this element. Therefore, using Zn sources with higher bioavailability may reduce the excretion of $\mathrm{Zn}$. This subject has been extensively researched in many countries, but no information in literature cited examines the effects of higher concentrations of $\mathrm{Zn}$ in the diet by combining conventional inorganic $\mathrm{Zn}$ sources $(\mathrm{ZnO})$ with organic sources, such as a $\mathrm{Zn}$ amino acid chelate on the growth performance, meat quality, and blood parameters of broilers. The objective of this study was to evaluate the effect of broiler diets supplemented with different forms and levels of $\mathrm{Zn}: \mathrm{ZnO}(80 \mathrm{mg} / \mathrm{kg})$ as inorganic source, or higher concentrations of $\mathrm{Zn}(122 \mathrm{mg} / \mathrm{kg})$ from a combination of ZnO with an organic Zn source (Availa-Zn120; Zinpro Corporation, Eden Prairie, MN, USA) on broiler performance, carcass and parts yields, meat quality and blood parameters.

\section{MATERIALS AND METHODS}

\section{Birds and experimental diets}

All procedures regarding bird handling and use are in accordance with guidelines set forth by the Jordanian Society for the Protection of Animals (SPANA, issued in 2007).

The experiment was conducted at poultry research farm of the University of Jordan. Birds were housed in a naturally-ventilated, open-sided chicken house divided in 16 floor pens. A total of 400 one-day-old, straight-run, commercial (Ross 308) broiler chicks were reared under standard management practices (Ross Management Guide, 2009).

Birds were fed one of two dietary treatments, each with eight replicates of 25 birds per replicate pen), in a completely randomized design. A regular corn-soybean pelleted diet was formulated for three rearing phases: starter (1-21 days), grower (22-35 d), and finisher (36-42 d), as are shown in Table 1. The two dietary treatments consisted of the basal diet supplemented with $80 \mathrm{mg} / \mathrm{kg}$ of $\mathrm{ZnO}$ (T1, control) as inorganic Zn source in the trace mineral premix, or the basal diet supplemented with $80 \mathrm{mg} / \mathrm{kg}$ of $\mathrm{ZnO}$ in the trace mineral premix plus $42 \mathrm{mg} / \mathrm{kg}$ of an organic $\mathrm{Zn}$ source added on top (zinc-methionine; Availa-Zn120; Zinpro Corporation, Eden Prairie, MN, USA), totaling $122 \mathrm{mg}$ of $\mathrm{Zn}$ per $\mathrm{kg}$ of diet (T2). The $\mathrm{Zn}$-amino acid chelate contained $12 \% \mathrm{Zn}$. The recommended dose for broilers is $350 \mathrm{~g} / \mathrm{MT}$ feed, which gives $42 \mathrm{~g}$ of $\mathrm{Zn}$ AA per MT of complete feed, given as per product feeding instructions of Zinpro (Zinpro Corporation) (Table 2). The composition of the experimental diets was analyzed according to the AOAC (2000).

Table 1 - \% Diet Composition

\begin{tabular}{|c|c|c|c|}
\hline \multirow{3}{*}{ Ingredient } & Starter & Grower & Finisher \\
\hline & $(0-21 d)$ & $(22-35 d)$ & $(36-42 d)$ \\
\hline & \multicolumn{3}{|c|}{$(\%)$} \\
\hline Corn & 55.75 & 59.85 & 64.15 \\
\hline Soybean meal (48 \% CP) & 38.00 & 32.50 & 28.00 \\
\hline Vegetable Oil & 2.10 & 3.50 & 3.70 \\
\hline Limestone (ground) & 1.60 & 1.60 & 1.60 \\
\hline Monocalcium phosphate & 1.13 & 1.05 & 1.05 \\
\hline $\mathrm{NaCl}$ & 0.25 & 0.25 & 0.25 \\
\hline DL-methionine (98\%) & 0.22 & 0.20 & 0.20 \\
\hline L-Lysine-HCI (98.5\%) & 0.25 & 0.23 & 0.23 \\
\hline Threonine & 0.06 & 0.05 & 0.05 \\
\hline Vitamin premix ${ }^{1}$ & 0.10 & 0.10 & 0.10 \\
\hline Mineral premix ${ }^{2}$ & 0.10 & 0.10 & 0.10 \\
\hline Choline Chloride (60\%) & 0.08 & 0.08 & 0.08 \\
\hline Coccsidiostat & 0.05 & 0.05 & 0.05 \\
\hline *Concentrate $2.5 \%$ & 0.31 & 0.44 & 0.44 \\
\hline \multicolumn{4}{|c|}{ NutrientChemical Composition: } \\
\hline $\mathrm{ME}, \mathrm{kcal} / \mathrm{kg}$ feed & 3,000 & 3,100 & 3,150 \\
\hline Crude Protein, \% & 22.50 & 19.50 & 18.50 \\
\hline Methionine, \% & 0.60 & 0.54 & 0.48 \\
\hline Lysine, \% & 1.40 & 1.25 & 1.10 \\
\hline Threonine, \% & 0.90 & 0.80 & 0.73 \\
\hline Tryptophan, \% & 0.24 & 0.22 & 0.20 \\
\hline $\mathrm{Ca}, \%$ & 1.00 & 0.90 & 0.85 \\
\hline P, non-phytate, \% & 0.48 & 0.45 & 0.45 \\
\hline \multicolumn{4}{|c|}{$\begin{array}{l}\text { 'Vitamin premix provided per kilogram of diet:vitamin } A, 120000 \mathrm{IU} \text {; vitamin } \mathrm{D}_{3^{\prime}} 3500 \\
\mathrm{IU} \text {; vitamin } \mathrm{E}, 40 \mathrm{mg} \text {; vitamin } \mathrm{B}_{1}, 2.5 \mathrm{mg} \text {; vitamin } \mathrm{B}_{2}, 8 \mathrm{mg} \text {; vitamin } \mathrm{B}_{6^{\prime}} 5.0 \mathrm{mg} \text {; vita- } \\
\text { min, riboflavin, } 150 \mu \mathrm{gg} ; \mathrm{B}_{12}, 30 \mu \mathrm{g} \text {; biotin, } 150 \mu \mathrm{g} \text {; folic acid, } 1.5 \mathrm{mg} \text {; niacin, } 45 \mathrm{mg} \text {; } \\
\text { pantothenic acid, } 13 \mathrm{mg} . .\end{array}$} \\
\hline \multicolumn{4}{|c|}{$\begin{array}{l}{ }^{2} \text { Trace mineral premix provided per kilogram of diet:Fe, } 60 \text { mg; Cu, } 10 \text { mg; Mn, } 80 \text { mg; } \\
\mathrm{Zn}, 80 \mathrm{mg} ; \mathrm{I}, 1 \mathrm{mg} ; \mathrm{Se}, 0.20 \mathrm{mg} \text {. }\end{array}$} \\
\hline $\begin{array}{l}{ }^{*} \text { Concentrate } 2.5 \% \text { contains: } \\
\text { Probiotic, } 0.025 \% \text { Coccidiosta }\end{array}$ & $\begin{array}{l}\text { ohosphol } \\
\text { iytase an }\end{array}$ & $\begin{array}{l}0.035 \% \mathrm{xyl} \\
5-0.185 \% \text { co }\end{array}$ & ase $0.025 \%$ \\
\hline
\end{tabular}


Zakaria HA, Jalal M, AL-Titi HH, Souad A
Effect of Sources and Levels of Dietary Zinc on the Performance, Carcass Traits and Blood Parameters of Broilers
Table 2 - Concentrations of Zn mg/kg in zinc supplements

\begin{tabular}{lcc}
\hline Zinc supplements & $\mathrm{T}_{1}$ & $\mathrm{~T}_{2}$ \\
\hline Zinc oxide & 80 & 80 \\
${ }^{1}$ Availa Zinc & - & 42 \\
\hline Total Zn in diets $(\mathrm{mg} / \mathrm{kg})$ & 80 & 122 \\
\hline
\end{tabular}

${ }^{1} \mathrm{Zn} 120$ was added on top of the diets containing $12 \% \mathrm{Zn}$, recommended dose for broilers 350g/MT

$120 \mathrm{~g} / \mathrm{kg}^{*} 0.35 \mathrm{~kg}=42 \mathrm{~g}$ of AA complexed Zn/MT of complete feed.

$\mathrm{T}_{1}$ :addition of $\mathrm{ZnO}$ in the trace mineral premix $(80 \mathrm{mg} / \mathrm{kg}$ ).

$\mathrm{T}_{2}$ :combination of $\mathrm{ZnO}$ in the trace mineral premix with Availa $\mathrm{Zn}$ added on top of diet $(122 \mathrm{mg} / \mathrm{kg})$

Daily temperatures were determined by a sensor located in the center of each room at $9 \mathrm{~cm}$ above the floor. Birds were given a 23L: 1D lighting regimen daily, and feed and water were provided ad libitum throughout the experiment. Birds were weighed upon arrival (initial body weight was $40 \pm 0.3 \mathrm{~g}$ ) and once a week until the end of the experiment (final body weights were $1930 \mathrm{~g}(\mathrm{~T} 1)$ and $1865.22 \mathrm{~g}$ (T2), as shown in Table 3).

Table 3 - Effect of levels and sources of Zn (inorganic and organic) on performance of broilers

\begin{tabular}{|c|c|c|c|c|}
\hline \multirow[t]{2}{*}{ Parameters } & \multicolumn{4}{|c|}{ Treatments $\left(\mathrm{ZnO}, \mathrm{T}_{1}\right)\left(\mathrm{ZnO}+\right.$ AvailaZn, $\left.\mathrm{T}_{2}\right)$} \\
\hline & $T_{1}$ & $\mathrm{~T}_{2}$ & $\mathrm{SEM}^{2}$ & $p$ value \\
\hline \multicolumn{5}{|c|}{ Body weight (g/bird): } \\
\hline \multicolumn{5}{|c|}{ Production Stages } \\
\hline $0-21$ days & 687.50 & 713.00 & 28.10 & NS \\
\hline $0-42$ days & 1950.50 & 1898.25 & 48.52 & NS \\
\hline \multirow{2}{*}{\multicolumn{5}{|c|}{$\begin{array}{l}\text { Body weight gain (g/bird): } \\
\text { Production Stages }\end{array}$}} \\
\hline & & & & \\
\hline $0-21$ days & 654.50 & 680.00 & 28.06 & NS \\
\hline $0-42$ days & 1930.00 & 1865.22 & 44.73 & NS \\
\hline \multicolumn{5}{|c|}{$\begin{array}{l}\text { Feed intake (g/bird): } \\
\text { Production Stages }\end{array}$} \\
\hline $0-21$ days & 845.50 & 825.25 & 25.43 & NS \\
\hline $0-42$ days & 3469.75 & 3345.75 & 53.69 & NS \\
\hline
\end{tabular}

Feed conversion ratio ( $\mathrm{g}$ feed $: \mathrm{g}$ bodyweight gain):

Production Stages

\begin{tabular}{lllll}
$0-21$ days & 1.34 & 1.32 & 0.0531 & NS \\
$0-42$ days & 1.76 & 1.82 & 0.0646 & NS \\
$\begin{array}{l}\text { Mortality rate (\%) } \\
\text { Production Stages }\end{array}$ & & & & \\
$0-21$ days & $4.50^{\mathrm{b}}$ & $1.00^{\mathrm{a}}$ & 0.530 & 0.02 \\
$0-42$ days & $4.80^{\mathrm{b}}$ & $1.25^{\mathrm{a}}$ & 0.638 & 0.01 \\
\hline
\end{tabular}

a-b Means within rows with varying superscripts differ significantly $(p<0.05)$ ${ }^{2} S E M: s t a n d a r d$ error of the mean ${ }^{3}$ Level of significance was set at $p<0.05$, NS: Not Significant

\section{Growth performance}

Production parameters were measured on a weekly basis per pen, and included feed intake (FI), feed conversion ratio ( $F C R)$, body weight (BW), and body weight gain (BWG). Mortality was observed and recorded daily; any bird that died was weighed, and its weight was used to correct both FI and FCR. Adjusted FCR was calculated using total feed intake per pen divided by the total weight gain of surviving birds and weight of birds that died or were removed from that pen.

\section{Sample collection for carcass evaluation and blood sampling}

On day 42 of the feeding trial, birds were fasted for 10 hours. Four birds per replicate (16 per treatment), with BW closest to the mean BW of the replicate were selected, weighed, and slaughtered according to animal welfare regulations in Jordan.

Two blood samples ( $3 \mathrm{~mL}$ ) were obtained from the wing vein of each bird and centrifuged at $3000 \mathrm{rpm}$ for $10 \mathrm{~min}$ to measure the blood levels of glucose, cholesterol, calcium (Ca), phosphorous $(\mathrm{P})$, total protein, albumin and $\mathrm{Zn}$ using commercial kits (Boehringer Mannheim Hitachi 704, automatic analyzer, Tokyo, Japan). All the analyses were carried out in duplicate.

After slaughter, birds were scalded in a water tank at $55^{\circ} \mathrm{C}-60^{\circ} \mathrm{C}$ for 30 seconds, and then plucked and eviscerated. Feet, shanks, neck, and head were removed, and carcasses were immediately weighed to obtain post-slaughter hot carcass weight without giblets. Giblets are the total yield of liver, heart and gizzard, which were removed and weighed, in addition to fat pad relative to body weight. Carcasses were refrigerated at $2^{\circ} \mathrm{C}-3^{\circ} \mathrm{C}$ for 24 hours, after which they were weighed to obtain cold carcass weight as a percentage of live weight (Asku et al., 2008). Carcasses were then dissected into different commercial parts (breast, thighs, and wings) to determine their yields. Parts yield were calculated relative to carcass weight and expressed as a percentage (Abdullah et al., 2010). Breast fillets were evaluated for the meat quality attributes $\mathrm{pH}$, color, water-holding capacity, cooking loss, and shear force.

\section{Meat quality measurements}

Meat $\mathrm{pH}$ values were determined by using the iodo acetate method (Jeacocke, 1977) on a pH meter (pH spear, model 35634-40, Eurotech Instruments, Malaysia). The $\mathrm{pH}$ was measured at three points in the cranial area of the pectoral superficial muscle (Pectoralis major) at about $5 \mathrm{~cm}$ from the sternum line (Abdullah \& Matarneh, 2010).

Color measurements were taken on the same area as the $\mathrm{pH}$ from each sample using a colorimeter (12 MM Aperture U 59730-30, Cole-Parameter International Inc., Pittsford, NY, USA). Three measurements were taken at each point on the medial portion of the 
pectoralis major muscle. Meat lightness $\left(L^{*}\right)$, redness $\left(a^{*}\right)$, and yellowness $\left(b^{*}\right)$ values were determined against a standard white ceramic reference.

Water-holding capacity (WHC) was measured (Barbut, 2002) based on the technique modified by Wilhelm et al. (2010)using a raw meat sample with initial weight of $5 \mathrm{~g}$ (one per replicate) Each sample was cut into smaller pieces and covered with two filter papers (qualitative, $185 \mathrm{~mm}$ circles, fine crystalline retention) and two thin plates of quartz material, then pressed with the weight of $2500 \mathrm{~g}$ for $5 \mathrm{~min}$. The meat samples were then removed from the filter paper, and their weight was recorded (final weight). WHC was calculated as the difference between the initial and final weight divided by the initial sample weight and expressed as a percentage (Al-Owaimer et al., 2014).

\section{Cooking loss and shear force measurements}

Breast samples of about $250 \mathrm{~g}$ were weighed and placed in sealed bags without air in a freezer at $-20^{\circ} \mathrm{C}$. Breast samples were then thawed, and removed from the plastic bags to determine weight loss. Samples were then individually placed in sealed plastic bags, cooked in a thermostatically-controlled water bath at $85^{\circ} \mathrm{C}$ for 25 minutes until maximum internal temperature of $80^{\circ} \mathrm{C}$ was achieved. Samples were then removed and put under running cold water to cool down for 45 minutes, then well dried and weighed to determine cooking loss. Cooking loss was calculated the percentage of cooked sample weight relative to fresh sample weight (Al-Owaimer et al., 2014).

The cooked pieces of meat were cut to obtain six cores $(20 \times 13 \times 13 \mathrm{~mm})$ of each breast sample $(6-8$ carrots of $1.25 \mathrm{~cm}$ diameter) using a metal cylinder to determine meat shear force according to Bratcher et al. (2005) (Warner-Bratzler Meat Shear Apparatus/ INSTRON, G-R Manufacturing Co., 1317 Collins LN, Manhattan, Kansas, 66502, USA).

\section{Statistical Analysis}

Data were submitted to analysis of variance (ANOVA) according to a completely randomized design using the PROC Mixed procedure of SAS (Version 9.4, SAS Institute Inc., Cary, NC, 2013). Pairwise differences between means were determined using PDIFF option of LSMEANS statement. The main effects of the two treatments with eight replicates each on growth performance, carcass yield, meat quality and blood parameters were tested. The overall level of statistical significance was set at $p<0.05$; tendencies were reported when $0.05 \leq p \leq 0.10$. Pen means were used as the experimental units for all variables evaluated.

\section{RESULTS}

\section{Growth Performance}

The evaluated treatments did not significantly affect BW, BWG, FI, and FCR (Table 3). The mortality rate (Table 3 ) recorded with the T2 diet (1.25\%) was significantly lower $(p<0.05)$ compared with that recorded with the T1 diet $(4.80 \%)$.

\section{Carcass yield, Meat Quality and Blood Parameters}

The different carcass traits studied were not affected when combining two different sources of $\mathrm{Zn}$ to the bird feed and the higher concentration of Zn (Table 4). Carcass and breast, thigh, wing, back, neck, fat pad and internal organs yields were not affected by Zn source or the high Zn concentration. Zinc source and level did not influence the meat quality attributes $\mathrm{pH}$, cooking loss, and water-holding capacity measured in 42-day-old broilers (Table 5). Meat color values $\left(L^{*}\right)$, redness $\left(a^{*}\right)$, and yellowness $\left(b^{*}\right)$ were not affected either. However, breast meat shear force was significantly higher $(p<0.05)$ in T2 compared with T1 (3.53 vs. $4.14 \mathrm{~kg} / \mathrm{cm}^{2}$ ).

Table 4 - Effect of levels and sources of Zn (inorganic and organic) on dressing, cuts percentages and organ weights of broilers

\begin{tabular}{|c|c|c|c|c|}
\hline \multirow[t]{2}{*}{ Parameters } & \multicolumn{4}{|c|}{ Treatments } \\
\hline & $\mathrm{T}_{1}$ & $\mathrm{~T}_{2}$ & SEM $^{1}$ & $p$ value $^{2}$ \\
\hline Carcass Weight (g) & 1908.42 & 1856.92 & 52.73 & NS \\
\hline Dressing yield ${ }^{3}(\%)$ & 74.74 & 75.10 & 1.58 & NS \\
\hline Fat Pad yield ${ }^{4}(\%)$ & 1.12 & 1.29 & 0.169 & NS \\
\hline Breast yield $5 \%$ ) & 34.90 & 35.10 & 1.64 & NS \\
\hline Thigh yield $(\%)$ & 28.39 & 27.81 & 0.937 & NS \\
\hline Wings yield 5 (\%) & 9.70 & 10.27 & 0.349 & NS \\
\hline Back yield 5 (\%) & 13.32 & 13.59 & 0.720 & NS \\
\hline Neck yield 5 (\%) & 13.40 & 13.39 & 0.559 & NS \\
\hline Liver Weight(g) & 55.42 & 50.83 & 3.52 & NS \\
\hline Heart Weight(g) & 13.30 & 14.16 & 1.22 & NS \\
\hline Gizzard Weight(g) & 27.50 & 25.00 & 1.74 & NS \\
\hline \multicolumn{5}{|c|}{${ }^{1}$ SEM:standard error of the mean } \\
\hline \multicolumn{5}{|c|}{${ }^{2}$ Level of significance was set at $p<0.05$} \\
\hline \multicolumn{5}{|c|}{${ }^{3}$ Carcass yield $=$ (cold carcass weight/live weight) ${ }^{*} 100 \%$} \\
\hline \multicolumn{5}{|c|}{${ }^{4}$ Abdominal fat $\%=$ (abdominal fat weight/cold carcass weight) ${ }^{*} 100 \%$} \\
\hline \multicolumn{5}{|c|}{${ }^{5}$ Parts yield $=$ (part weight/cold carcass weight) ${ }^{*} 100 \%$} \\
\hline \multicolumn{5}{|c|}{$\mathrm{T}_{1}: \mathrm{ZnO}(80 \mathrm{mg} \mathrm{Zn} \mathrm{/} \mathrm{Kg).}$} \\
\hline \multicolumn{5}{|c|}{$\mathrm{T}_{2}: \mathrm{ZnO}+$ Availa Zn (122 mg Zn /Kg). } \\
\hline \multicolumn{5}{|c|}{ NS:Not significant } \\
\hline
\end{tabular}

The treatments did not significantly affect the blood parameters of broilers chicks, except for $P(\mathrm{mg} / \mathrm{dL})$, total protein $(\mathrm{mg} / \mathrm{dL})$ and $\mathrm{Zn}(\mathrm{ug} / \mathrm{dL})$ (Table 6). 
Table 5 - Effect of levels and sources of Zinc (inorganic and organic) on meat quality characteristics of broilers

\begin{tabular}{lcccc}
\hline Parameters & \multicolumn{3}{c}{ Treatments } \\
\hline Breast pH (24 $\mathrm{h}$ post mortem) & $\mathrm{T}_{1}$ & $\mathrm{~T}_{2}$ & SEM $^{1}$ & $\mathrm{p}$-Value \\
Breast cooking loss (\%) & 5.93 & 5.92 & 0.007 & $\mathrm{NS}$ \\
Breast water holding capacity (\%) & 31.94 & 31.98 & 0.51 & $\mathrm{NS}$ \\
Breast meat shear force $\left(\mathrm{kg} / \mathrm{cm}^{2}\right)$ & 37.63 & 35.56 & 1.45 & $\mathrm{NS}$ \\
$\mathrm{L}^{*}$ (Breast meat lightness) & $4.14^{\mathrm{a}}$ & $3.53^{\mathrm{b}}$ & 0.41 & 0.02 \\
$\mathrm{a}^{*}$ (Breast meat redness) & 52.13 & 51.50 & 1.97 & $\mathrm{NS}$ \\
$\mathrm{b}^{*}$ (Breast meat yellowness) & 3.52 & 3.38 & 0.24 & $\mathrm{NS}$ \\
\hline
\end{tabular}

${ }^{a-b}$ Means within rows with varying superscripts differ significantly $(p<0.05)$

'SEM:standard error of the mean

'Level of significance was set at $p<0.05$

$\mathrm{T}_{1}: \mathrm{ZnO}(80 \mathrm{mg} \mathrm{Zn} / \mathrm{Kg})$.

$\mathrm{T}_{2}: \mathrm{ZnO}+$ Availa Zn (122 mg Zn/Kg).

NS:Not significant

Table 6 - Effect of levels and sources of Zinc (inorganic and organic) on the blood analysis of broilers

\begin{tabular}{lcccc}
\hline Parameters & \multicolumn{4}{c}{ Treatments } \\
\hline & $\mathrm{T}_{1}$ & $\mathrm{~T}_{2}$ & SEM $^{1}$ & $p$-Value \\
\hline Glucose $(\mathrm{mg} / \mathrm{dL})$ & 215.63 & 209.25 & 11.38 & $\mathrm{NS}$ \\
Cholesterol $(\mathrm{mg} / \mathrm{dL})$ & 99.88 & 100.50 & 9.23 & $\mathrm{NS}$ \\
Calcium $(\mathrm{mg} / \mathrm{dL})$ & 9.74 & 10.66 & 0.495 & $\mathrm{NS}$ \\
Phosphate $(\mathrm{mg} / \mathrm{dL})$ & $6.16^{\mathrm{b}}$ & $7.56^{\mathrm{a}}$ & 0.332 & 0.01 \\
Total Protein $(\mathrm{mg} / \mathrm{dL})$ & $3.33^{\mathrm{b}}$ & $3.63^{\mathrm{a}}$ & 0.198 & 0.05 \\
Albumin $(\mathrm{mg} / \mathrm{dL})$ & 1.07 & 1.10 & 0.036 & $\mathrm{NS}$ \\
Zinc $(\mathrm{ug} / \mathrm{dL})$ & $149.13^{\mathrm{b}}$ & $186.88^{\mathrm{a}}$ & 13.06 & 0.05 \\
\hline
\end{tabular}

a-b Means within rows with varying superscripts differ significantly $(p<0.05)$

ISEM:standard error of the mean

2Level of significance was set at $p<0.05$

$\mathrm{T}_{1}: \mathrm{ZnO}(80 \mathrm{mg} \mathrm{Zn/Kg})$.

$\mathrm{T}_{2}: \mathrm{ZnO}+$ Availa Zn (122 mg Zn/Kg)

NS:Not significant

\section{DISCUSSION}

\section{Growth performance}

Performance responses were not significantly different between the $\mathrm{Zn}$ levels and sources of used. Previous studies have shown no effect of $Z n$ source on growth performance (Jondreville et al., 2007; Rossi et al., 2007; Schlegel et al., 2010; Anil et al., 2012; Salim et al., 2012). Saenmahayak et al. (2010) reported that, regardless of its form, the dietary supplementation of $\mathrm{Zn}$ in excess of $40 \mathrm{mg} / \mathrm{kg}$ of diet did not improve the growth rate of male broilers. Anil et al. (2012) stated that the supplementation of inorganic or organic $\mathrm{Zn}$ at $20,40,60$, and 80 ppm levels did not influence feed intake of broilers. Sandoval et al. (1999) and Jahanian et al. (2008) also observed that inclusion of organic Zn sources had no beneficial effect on broiler feed efficiency. However, Kucuk et al. (2003), Burrell et al. (2004), and Ao et al. (2006) reported improvements in the growth performance, weight gain and feed efficiency of broilers when organic Zn was added above the NRC recommendation levels. Performance alone may not be a good indicator of the $\mathrm{Zn}$ requirements of broilers, especially when corn-soybean meal diets are fed, possibly because these ingredients contain the minimum Zn levels required for growth (Huang et al., 2007).

Mortality rate during the rearing period was significantly lower $(p<0.05)$ in T2-fed birds $(1.25 \%)$ compared with those fed the T1 diet (4.80\%), as shown in Table 3. This reflects the role of $\mathrm{Zn}$ in stimulating the development of the immune system, as providing a sufficient bioavailable $\mathrm{Zn}$ source results in healthier birds and decreases mortality (Salim et al., 2011).

The inconsistent effects of dietary $\mathrm{Zn}$ on broiler growth performance have been attributed to several factors, such as the amount of $\mathrm{Zn}$ present in the basal diet (Leeson \& Summers 2005), the selective metabolism of $\mathrm{Zn}$ by different enzymes that affect some parameters of broiler performance, differences in the physical-chemical properties of the supplemented Zn source used (Zhao et al., 2010), and the presence of other dietary ligands, such as phytate and $\mathrm{Ca}$, which form insoluble complexes with $\mathrm{Zn}$ and interfere with its absorption (Salim et al., 2012).

\section{Carcass yield, Meat Quality, and Blood Parameters}

The different carcass traits evaluated in this study were not affected by different $\mathrm{Zn}$ sources fed to broilers (Table 4). This is consistent with Liu et al. (2011), who stated that dietary Zn levels and sources did not influence the abdominal fat percentage or the carcass traits of broilers. Rossi et al. (2007) and Anil et al. (2012b) reported that carcass yields were 
not influenced by the addition of dietary organic Zn or when different levels of inorganic $\mathrm{Zn}$ and $\mathrm{Mn}$ were fed to broilers. Savari et al. (2015) concluded that there was no influence of $\mathrm{ZnO}$ on carcass traits. Jahanian et al. (2008) observed that dietary Zn levels of up to $40 \mathrm{mg} /$ $\mathrm{kg}$ did not have any significant effect on cooked-meat yield, in contrast with results obtained by Wojciech et al. (2007), who demonstrated the positive influence of organic Zn forms on the percentage of breast muscles in the carcass. Tronina et al. (2007) stated that organic $\mathrm{Zn}$ could increase the proportion of breast and leg muscles, dressing percentage and fat content in the breast and leg muscles of broilers. Liver and heart weights were not significantly different between the T2 group and the T1 group, in contrast with Jahanian et al. (2008), who reported that increasing Zn supplemental levels from 40 to $80 \mathrm{mg} / \mathrm{kg}$ from both inorganic and organic Zn sources increased liver weight percentage. Several factors may affect the final results of the trials, such as Zn source and concentrations, management practices applied, or environmental conditions under which experiments were conducted.

The meat quality indices evaluated in this study were not affected by Zn source or level, except for meat shear force. Meat color is one of the indicators of meat quality, and Zn has the ability to bind myoglobin and increase its oxygenation, which allows the maintenance of meat color; however, no significant effect on meat color was detected in our study. Our results are partially consistent with work conducted by Saenmahayak et al. (2010) in terms of carcass weight and parts yields, but in contrast with breast color, as those authors reported an increase in the redness $a$ * value of the breast meat.

Breast meat shear force was significantly different between broilers fed inorganic $\mathrm{Zn}(\mathrm{ZnO})$ and the higher $\mathrm{Zn}$ level of the combination of $\mathrm{ZnO}$ with $\mathrm{Zn}-\mathrm{AA}$ (AvailaZn 120). Lower shear force value $(p<0.05)$ in the $T 2$ group compared with the T1 group $\left(3.53 \mathrm{~kg} / \mathrm{cm}^{2}\right.$ vs. $\left.4.14 \mathrm{~kg} / \mathrm{cm}^{2}\right)$ is an indication that meat from the T1 group was tougher and less juicy, since a greater SF value indicates lower meat tenderness. Organic and higher concentrations of Zn mixed with the inorganic source improved meat quality by helping to hold cells more tightly together in discrete units (Rossi et al., 2007) and to promote protein synthesis, collagen formation and optimal activity of the enzymes that affect meat quality (Saenmahayak et al., 2010). Many factors influence meat tenderness, such as age, sex, and dietary factors (Salim et al., 2012; Devrim et al., 2009), and this may explain the contradictory results obtained in different trials conducted. There is limited information on the effects of organic $\mathrm{Zn}$ sources on broiler carcass and meat quality, and further experiments are needed to elucidate the effect of $\mathrm{Zn}$ on meat quality (Hesset al., 2001).

Blood parameters were not affected by the two sources of $\mathrm{Zn}$ except for $\mathrm{P}$, total protein and $\mathrm{Zn}$ concentration (Table 6). This is in agreement with Sarvari et al., (2015), who reported that serum parameters were not affected by $\mathrm{ZnO}$. Higher blood total protein levels may be explained by the increase in the digestion time with slower passage time of feed in the digestive tract owing to the action of organic $\mathrm{Zn}$ since it plays a major role in the body enzyme system, physiology, metabolism and growth and it is necessary to promote protein synthesis (Berger, 2006). Feng et al. (2009) reported increased serum total protein and calcium concentrations when zinc-glycine chelate was added to the diet. However, Barman et al. (2009) did not report any significant effect of different dietary Zn supplementation levels on serum protein concentration. Jahnian \& Rasouli (2015) reported no effects on plasma zinc concentration when inorganic zinc was replaced by $\mathrm{Zn}$-methionine. Increased blood $\mathrm{Zn}$ levels are used as an indication of its biological availability in live animals (Liu et al., 2011). Similar findings were reported by Mohanna \& Nys (1999) and Anil et al. (2012), who observed that blood Zn concentration increased with dietary Zn content. Ao et al. (2009) and Johnson \& Fakler (1998) also stated that feeding premixes containing organic forms of chemical bonds of $\mathrm{Zn}$ (Zn-methionine and amino-acid $\mathrm{Zn}$ complex) resulted in higher blood $\mathrm{Zn}$ levels. The increase in serum $\mathrm{Zn}$ levels is related to the higher absorption and lower interaction with other organically-complexed minerals in the digestive tract compared with inorganic trace minerals, increasing the bioavailability of $\mathrm{Zn}$ bound to amino acids/proteins, and therefore it is easily absorbed because of such structures (Devrim et al., 2009).

The higher $\mathrm{P}$ level in the $\mathrm{T} 2$ group relative to $\mathrm{T} 1$ may be explained by the interrelation between $\mathrm{Zn}$ and $\mathrm{P}$, since $\mathrm{P}$ plays a major role in bone formation, and $\mathrm{Zn}$ deficiency results bone abnormalities (Collins et al., 1991). Phosphorus is usually present in meat in the form of phosphates that significantly contribute for the water-holding capacity of meat, which is related to shear force (Kucuk et al., 2008). Feng et al. (2009) reported no effect on blood $\mathrm{P}$ levels when zinc-glycine was added to the diet. $\mathrm{Zn}$ is present in all cells and participates in a wide variety of metabolic processes, 
Effect of Sources and Levels of Dietary Zinc on the Performance, Carcass Traits and Blood Parameters of Broilers and $\mathrm{Zn}$ enzymes are involved in the biosynthesis and degradation of carbohydrates, lipids, proteins, and nucleic acids (Kaim \& Scwederski, 1994).

\section{CONCLUSIONS}

Performance responses were not significantly affected by the evaluated $\mathrm{Zn}$ levels and sources, and therefore, either source of supplemental $Z n$ can be used in broiler diets without affecting bird performance.

The broilers fed with the highest dietary Zn level from both organic and inorganic sources presented higher $\mathrm{Zn}, \mathrm{P}$, and total protein levels relative to the lower levels evaluated.

Future research on dietary Zn supplementation will aid understanding both the absorption mechanisms and metabolic pathways of different $\mathrm{Zn}$ sources and their effects on meat quality.

Conclusions are based on this trial only and cannot be drawn upon by the basis of $\mathrm{Zn}$ sources and levels applied.

\section{ACKNOWLEDGEMENTS}

The authors would like to thank the Istisharia Company for poultry feed presented by Eng. Insan Mousharbash and Eng. Mouhammad Al Malah and Dr. Khaled Qasem from Zinpro Corporation for providing the Availa-Zn 120 product and for their continuous support.

The manuscript does not contain clinical studies or patient data.

\section{CONFLICT OF INTEREST}

\section{None}

\section{REFERENCES}

Abdullah AY, Matarneh SK. Broiler performance and the effects of carcass weight broiler sex and postchill carcass aging duration on breast fillet quality characteristics. Journal of Applied Poultry Research 2010;19(1):46-58.

Abdullah AY, Mahmoud KZ, Nusairat BM, Qudsieh RI. Small intestinal histology, production parameters and meat quality as influenced by dietary supplementation of garlic (Allium sativum) in broiler chicks. Italian Journal of Animal Science 2010;9(4):e 80

Al-OwaimerAN, Suliman GM, Alyemni AH, Abudabos AM. Effect of different probioticson breast quality characteristics of broilers under Salmonella challenge. Italian Journal of Animal Science 2014;13(3):450-454.

Anil KC, Ramana JV, Rama PJ, Sudheer SD, Satyanarayana RPVV. Influence of zinc sulphate and zinc-methionine dietary supplementation on carcass characteristics and feed efficiency of broilers. Annals of Biological Research 2012;3(8):4215-4221.
Anil KC, Ramana JV, Rama PJ, Sudheer SD, Shakeela S. Dietary supplementation of Zinc sulphate and zinc-methionine:changes in levels of Mineral composition. Journal of Animal Production Advances 2012;2(9):409-419

AOAC - Association of Official Analytical Chemists. Official methods of analysis. $17^{\text {th }}$ ed. Washington; 2006.

Ao, T, Pierce Jl, Power R, Dawson KA, Pescator AJ, Cantor AH, Ford MJ. Evaluation of bioplex $\mathrm{Zn}$ as organic zinc source for chicks. International Journal of Poultry Science 2006;5(9):808-811.

Ao T, Pierce JL, Power R, Pescatore AJ, Cantor AH, Dawson KA, et al. Effects of feeding different forms of zinc and copper on the performance and tissue mineral content of chicks. Poultry Science 2009;88(10):2171-5.

Aksu MI, Imik H, Karaoglu L. Influence of dietary Sorghum(Sorghum vulgare) and Corn supplemented with methionine on cut up pieces weights of broiler carcass and quality properties of breast and drumsticks meat. Journal of Food Science and Technology International 2007;13(5):361367.

Bao YM, Choct M, iji PA, Bruerton K. Effect of organically complexed copper, iron, manganese, and zinc on broiler performance, mineral excretion, and accumulation of tissues. Journal of Applied Poultry Research 2007;16(3):448-455.

Barman C, Goswami J, Sameh BC. Effect of zinc supplementation on feed consumption and growth performance of broiler chicks. International Veterinary Journal 2009;86(11):1154-1155

Barbut S. Water holding capacity In: Barbut, S. Poultry products processing: an industry guide. Boca Raton: CRC Press ; 2002.

Berger LL. Trace minerals In: Cunha TJ. Salt and trace minerals for livestock poultry and other animals. Alexandria: Salt institute; 2006. p.63-64.

Bratcher CL, Johnson DD, Litell RC, Gwartney BL. The effects of quality grade, aging and location within muscle on Warner-Bratzier shear force in beef muscles of locomotion. Meat Science 2005;70(2):279-284.

Burrell AL, Dozier WA, Davis AJ, Compton MM, Freeman ME, Vendrell PF, et al. Responses of broilers to dietary zinc concentrations and sources in relation to environmental implications. British Poultry Science $2004 ; 45(2): 225-263$

Chand N, Naz S, Khan A, Khan S, Khan RU. Performance traits and immune response of broiler chicks treated with zinc and ascorbic acid supplementation during cyclic heat stress. International Journal of Biometeorology 2014;58(10):2153-2157

Cheng TK, Fakler TM, Rappm CJ, Ward TL. Organic versus inorganic trace minerals in poultry: the zinc experience. Proceedings of the 32th Annual Carolina Poultry Nutrition Conference; 2005; Eden Prairie: Zinpro Corporation; 2005.

Collins NE, Moran ET. Influences of supplemental manganese and zinc on live performance and carcass quality of diverse broiler strains. Journal of Applied Poultry Research 1999;8(2):228-235.

Devrim SA, Taylan A, Bülent Ö. The effects of lower supplementation levels of organically complexed minerals (zinc, copper and manganese) versus inorganic forms on hematological and biochemical parameters in broilers. Kafkas University. Veterinary Faculty Research 2009;16(4):553559.

Feng J, MaWQ, Niu HH, Wu XM, Wang Y, Feng J. Effects of zinc glycine chelate on growth, haematological, and immunological characteristics in broilers. Biological Trace Element Research 2010;12(7):503-516.

Huang YL, Lu L, Luo XG, Liu B. An optimal dietary zinc level of broiler chicks fed a corn-soybean meal diet. Poultry Science 2007;86(12):2582-2589. 
Hess GB, Bilgili SF, Parsonm AM, Downs KM. Influence of complexed zinc products on live performance and carcass grade of broilers. Journal of Applied Poultry Research 2001;19:49-60.

Jahanian R, Moghaddam HN, Rezaei A, Haghparast AR. The influence of dietary zinc-methionine substitution for zinc sulfate on broiler chick performance. Journal of Biological Science 2008b;8(2):321-327.

Jahanian R, Rasouli E. Effects of dietary substitution of zinc-methionine for inorganic zinc sources on growth performance, tissue zinc accumulation and some blood parameters in broiler chicks. Journal of Animal Physiology and Animal Nature 2015;99(1):50-58.

Jeacocke RE. Continuous measurement of the $\mathrm{pH}$ of beef muscle in intact beef carcasses. Journal of Food Technology 1977;12(4):375-386.

Jondreville $C P$, Lescoat Mangin M, Feurstein D, Gruenbergm B, Nys $Y$. Sparing effect of microbial phytase on zinc supplementation in maizesoybean meal diets for chickens. Animal 2007;1(6):804-811.

Johnson TM, Fakler AB. Trace minerals in swine and poultry nutrition [technical bulletin]. Eden Prairie: Zinpro Corp; 1998. p. 1-24

Kaim W, Scwederski B. Bioinorganic chemistry of life. London: John Wiley \& Sons; 1994. p.40.

Kucuk O, Sahin N, Sahin K. Supplemental zinc and vitamin A can alleviate negative effects of heat stress in broiler chickens. Biological Trace Element Research 2003;94(3):225-235.

Kucuk O, Kahraman A, Kurt I, Yildiz N, Onmaz AC. A combination of zinc and pyridoxine supplementation to the diet of laying hens improves performance and egg quality. Biological Trace Elements Research 2008;126(1):165-175.

Leeson S, Summers JD. Commercial poultry nutrition. $3^{\text {rd }}$ ed. Guelph: University Books; 2005.

Liu ZH, Lu L, Li SF, Zhang LY, Xi L, Zhang KY, et al. Effects of supplemental zinc source and level on growth performance, carcass traits, and meat quality of broilers. Poultry Science 2011;90(8):1782-1790.

Mohanna C, Nys Y. Effect of dietary Zinc content and sources on the growth, body zinc deposition and retention, zinc excretion and immune response in chickens. British Poultry Science 1999;40(1):108-114.

NRC- National Research Council. Nutrient requirements of poultry. $9^{\text {th }}$ ed. Washington: National Academy Press; 1994.

Pimental JL, Cook ME, Greger JL. Immune response of chicks fed various levels of zinc. Poultry Science Journal 1991;70(4):947-954.

Rossi P, Rutz F, Ancuiti MA, Rech JL, Zauk NHF. Influence of graded levels of organic zinc on growth performance and carcass traits of broilers. Journal of Applied Poultry Research 2007;16(2):219-225.

Ross Management Guide. Broiler management guide 308. 2009. Available from: www.aviagen.com

Saenmahayak SF, Bilgilli JB, Singh, H. Live and processing performance of broiler chickens fed diets supplemented with complexed zinc. Journal of Applied Poultry Research 2010;19(4):334-340.
Salim HM, Lee HR, Jo C, Lee SK, Lee BD. Effect of sources and levels of zinc on the tissue mineral concentration and carcass quality of broilers. Avian Biological Research 2010;3(1):23-29.

Salim HM, Lee HR, Jo C, Lee SK, Lee BD. Supplementation of graded levels of organic zinc in the diets of female broilers; effects on performance and carcass quality. British Poultry Science 2011;52(5):606-612.

Salim HM, Lee HR, Jo C, Lee SK, Lee BD. Effect of sex and dietary organic zinc on growth performance, carcass traits, tissue mineral content and blood parameters of broiler chicken. Biological Trace Element Research 2012;147(1-3):120-129.

Sandoval M, Henry PR, Little RC, Miles RD, Butcher GD, Ammerman CB. Effect of dietary zinc source and method of oral administration on performance and tissue trace mineral concentration of broiler chicks. Journal of Animal Science 1999;77(7):1788-1799.

Schlegel P, Nys Y, Jondreville C. Zinc availability and digestive zinc solubility in piglets and broilers fed diets varying in their phytate contents, phytase activity and supplemented zinc source. Animal 2010;4(2):200-209.

Sarvari BG, Seyedi AH, Shahryar HA, Sarikhan M, Ghavidel SZ. Effects of dietary zinc oxide and a blend of organic acids on broiler live performance, carcass traits and serum parameters. Brazilian Journal of Poultry Science 2015;17(spe):39-46.

SAS - Statistical Analysis System. User's guide: statistics: version 9.4. Cary: SAS Institute; 2013

Swiatkkiewicz S, Koreleski J, Zhong D. The bioavailability of zinc from inorganic sources in broiler chickens as affected of phytase. Journal of Animal Feed Science 2001;10(2):317-328

Tronina W, Kinal S, Lubojemska B. Effect of various forms of zinc applied in concentrate mixtures for broiler chickens on its bioavailability as well as meat composition and quality. Polish Journal of Food Nutrition Science 2007;57 Suppl 4C:577-581

Willhelm AE, Maganhini MB, Hernandez-Blazquez FJI da, Shmokomaki M. Protease activity and the ultrastructure of broiler chicken PSE(pale, soft exudative) meat. Food chemistry 2010;119(3):1201-1204.

Wojciech T, Stefania K, Barbra I. Effect of various forms of zinc applied concentrate mixtures for broiler chickens on its bio availability as well as meat composition and quality. Polish Journal of food Nutrition Science 2007;57(4):577-581.

Yuan J, Waldroup PW. Evaluation of Mintrex manganese as a source of manganese for Young broilers. International journal of Poultry Science 2006:5(8):708-713.

Zhao J, Shirley RB, Vazquez-Anon M, Dibner JJ, Richards JD, Fisher P, et al. Effects of chelated trace minerals on growth performance, breast meat yield, and foot pad health in commercial meat broilers. Journal of Applied Poultry Research 2010;19(4):365-372. 